\title{
THE CIVIL COURTS AND DETERMINATION OF NATIVE CUSTOMARY LAND RIGHTS: MERELY DECLARING OR MAKING LAWS?
}

\author{
Ramy Bulan \\ Faculty of Law \\ University of Malaya \\ Kuala Lumpur, Malaysia \\ (ramybulan@gmail.com; ramy@um.edu.my) \\ DOI: https://doi.org/10.22452/brj.vol13no1.1
}

\begin{abstract}
It is often said that laws are made by legislature and the judges' role is only to declare and to interpret those laws. In interpreting the laws, the courts apply laws to new situations thereby developing the law. Indeed, judicial decisions have an important role in clarifying customary rights to land based on native laws and customs in Malaysian Borneo. Although breaches of native laws and customs are within the jurisdiction of the state Native Courts, major disputes over land rights which involve non-native parties have been fought in the federal system of civil courts. This paper looks at judicial decisions relating to the customary practice of pemakai menoa, and argues that recognition of land rights begin with recognition of indigenous legal traditions. To achieve justice and equality, and to prevent the law from being oppressive, the courts must make a conscious inquiry and contextual application of customs. In the light of inherent evidentiary difficulties in adjudicating native claims, this means approaching the rules of evidence, giving due weight to the unique perspectives, the normative values and rights under indigenous legal traditions and customary laws.
\end{abstract}

Keywords: native law and customs, native customary rights to land, judicial contextualisation, Pemakai Menoa and territorial rights, Pulau, role of judges

\section{Introduction}

The High Court below and this court do not assume to have the power to change, modify or alter the Native Customary Law of Sarawak; nor do we have any intention of doing so. We are only here to ascertain and to declare the native's customary right to land. And we have no doubt whatsoever 
that under the Federal Constitution and the law of Sarawak we have the power to do so. (Per Abdul Wahab Patail JCA, in Director of Forests $v$ TR Sandah Tabau \& Ors [2014] 1 MLJ 101 At 183 para. 42)

Law in Malaysia includes both written and unwritten law. Statutory laws, are passed by legislative bodies and are contained in Acts, Enactments or Ordinances, whereas unwritten laws are principles that are developed through judicial decisions, which are called case laws. The latter include interpretations of statutory provisions by the courts. In common law jurisdictions, the courts are subject to the rule of judicial binding precedents, or the doctrine of stare decisis (literally to stand by what has been decided). This doctrine requires courts not only to follow earlier precedents but, in specific circumstances, courts in a subsequent case are bound to do so, whether or not the judge agrees with the precedent in question (Hamzah \& Bulan, 2003). The rationale for the observance of precedents is that, when a higher court in the same hierarchy and jurisdiction has laid the applicable law in a case where the material facts are similar, a lower court must follow the earlier decision unless it can distinguish the case on the facts. Decisions of superior courts outside that hierarchy or jurisdiction, though not binding, maybe followed out judicial comity or respect for the standing of the court in question. It is through this process that the common law has developed.

In recent years judicial decisions on rights based on native laws and customs and the recognition of customary rights to land has been at the cutting edge of the development of law in Malaysia. This is in tandem with the resurgence of customary laws and international consciousness of indigenous peoples rights couched in principles of human rights. The challenge for the courts is to apply the concepts of native laws and customs in a rapidly changing environment without "crystalising" and freezing the principles in a past age, or interpreting the principles through the conceptual lenses of a different normative system, which could result in customary laws losing their vitality as living laws.

This paper intends to consider how the courts can employ customary laws to achieve justice and equality and prevent the law from being oppressive, particularly with regards to native customary land rights. It looks at how the evidentiary rules and methods of proof may take into account the uniqueness of customary laws and the rights that accrue thereunder, thereby treating them as fundamental rights protected by the Federal Constitution. Since all laws and actions of administrators must be measured against the Constitutional 'plumb line', to say that a right is protected as a fundamental right by the Federal Constitution elevates its status and imposes an obligation on the government with respect to actions potentially affecting those rights. This requires a proper 
understanding of native laws and customs as a source of law that is applied in its proper context.

Historically, the British colonial administration in Malaysia left an important legacy of an established legal system based on the English common law tradition. It was the British policy to apply English common law, adapted to the conditions and wants of the "alien races" in so far as the religions, manners and customs of the local inhabitants permitted. This was to prevent the common law from operating unjustly and oppressively (Choa Choon Neo v. Spottiswoode, 1835,) and to avoid hardship to the local inhabitants (Choo Ang Choo v Neo Chan Neo, 1911). In the case of In the Goods of Abdullah"1869, Benjamin Malkin recognised that religions and customs of the local inhabitants were recognised as 'personal laws as an exception to the general common law. An excellent explication was given by Mark D. Walters (1999) of the doctrine of continuity which presumed that the crown intended to respect native laws and customs and native rights, except in so far as they were incompatible with the Crown's assertion of sovereignty (Campbell $v$ Hall [1771] Lofft 6555, 1 Cowp. 204, 98 ER 848 [K.B], In Malaysia, although the accommodation and adaptations were somewhat eclectic, on the whole, the preexisting adat or customary laws of the various "alien races" applied as personal laws (Choa Choon Neo v Spottiswoode, 1835).

In both Sabah and Sarawak, native laws and customs were given recognition in the earliest formulation of statutory laws. In Sabah, article 9 of the North Borneo Charter provided that "regard must be had to customs and laws ...of the natives ' and in Sarawak, the Brookes' recognition of the existence of a system of law based on native customs featured in the earliest Land Orders of 1920. English law applied in Sabah through the Civil Law Ordinance 1938 and the North Borneo Application of Laws Ordinance of 1951, and in Sarawak, through the Application of Laws Ordinance 1928. Upon the cession of Sarawak to Britain in 1946 (Order No C-20, Sarawak Government Gazette), English common law and doctrines of equity were received afresh through the Application of Laws Ordinance 1949 (Ordinance No 27 of 1949) to be applied only to the extent rendered necessary by local circumstances and native customs (Cap 2 of Laws of Sarawak). This signified the continued recognition of native customary laws, as the Brookes had done through the Rajah's Order No L-4 in 1928. In Sabah, the modifications to English laws by local customary laws were only to the extent that such customary laws were "not inhumane, unconscionable or contrary to public policy". These provisions are reproduced in the Civil Law Act 1956 (Act 67) (Revised 1972) It cannot be understated that personal laws are applied to avoid any form of oppression on those who are governed by those laws and so the 
interpretation of the legislation should be interpreted in the light of the foundational principle.

Today, Malaysia's national legal system is a plural legal system with integration of legislation, common law, customary laws as well as syariah laws, administered through federal and state courts. The Civil Courts are federal courts and Syariah and Native Courts are state courts. In Sarawak and Sabah, breaches of native customary laws, are tried in a system of Native Courts where both parties are natives, and this includes Muslim natives, in matters concerning them that are not covered by the Syariah Court (Idid, 1993). Although personal laws under the jurisdiction of Native Courts were initially related to religious and family laws, they have extended to proprietary rights established under customary laws. Accurate application of those laws requires an understanding of native laws and customs as a source of law.

\section{Customs as a source of law}

The definition of law under Art 160(2) of the Federal Constitution states that law "includes written law, the common law..." and "any custom or usage having the force of law in the Federation or any part thereof" making customary law an integral part of the legal system. Federal and state legislative powers are divided between Federal and State with List I as Federal and List II being the state list with matters of religion, customs, land, forestry and local government coming under the purview of the state. Despite this division of power, in a state of emergency, if required, Art 150(5) of the Federal Constitution allows Parliament to make laws with respect to any matter, including matters under the states' legislative powers. Clause 6A of Art 150, however, states that this power does not extend to Malay adat or to any matter of native law, customs and usages in the states of Sabah and Sarawak. This indicates the unique protection and weight of recognition that is intended for rights based on customs. This was part of the rights negotiated by the founding fathers at the formation of Malaysia. The Consultative Committee envisaged that native rights to practise their customary laws would not be affected. The record of the discussion of the Consultative Committee brings this out very clearly.

The term customary law is used interchangeably to refer to adat, traditional law, tribal law, or native law and custom, distinguishing it from the system of laws known to the state legal-juridical system, which is based on common law. The literature on adat and customary law often uses the two terms interchangeably (Langub, 1998). Adat is commonly used to refer to customs, but it can also mean the natural order or rules of law, legal usages and concept of law (Hooker, 1972). The 
generic term for that body of customs is 'adat', which the Dutch had developed into the adatreitcht (Burns, 2004; Hooker, 1978; Vollenhoven, 1933; Ter Haar, 1948). Adat pervades and regulates the whole native way of life. In that sense, it is not only 'fashion' or acceptable behaviour but has a coercive force. It refers to an established system of immemorial rules or patterns of social behaviour which, through long-term usage and common consent of the community, are accepted by a given society as beneficial and binding upon itself, as a means of generating harmonious interpersonal relations and solving conflicts in order to maintain a cohesive society. A custom would be upheld if it was of great antiquity and dating back to time immemorial, meaning that in the absence of sufficient rebutting evidence there is "proof of the existence of the custom as far back as living witnesses can remember" (Nor anak Nyawai v Borneo Pulp Plantations \& Ors [2001]). Established customs become the accepted norm or the law of the place (Benson Maxwell in Sahrip $v$ Mitchell \& Anor [1877] Leic. Reports 466), and the leadership will use the coercive powers they may possess to ensure compliance. These customary laws include norms of correct social behaviour, prescribed rules for ceremonies including marriage and religious rites, agricultural systems (Langub, 1998) and settlement of disputes involving community membership, kinship, leadership feuds, resource access and property rights.

Customary laws are largely unwritten, but in Sarawak, the Majlis Adat Istiadat (Council for the Preservation of Customs) which was set up within the Sarawak Chief Minister's department has compiled and codified the customs of the various native groups. The earliest "codes" were the Adat Iban Order of 1993 and the Adat Bidayuh Order, 1994 followed by various codes that were drafted for most of the native groups in Sarawak. The term code is used loosely here to mean a systematised record of the adat. They followed the chapter structure used in the Iban Adat Order, 1993. Concepts of Iban customary laws were identified and translated into terminologies that were acceptable to Iban throughout Sarawak, which are also suitable for administrative purposes. According to Langub (1998), some provisions of the Tusun Tunggu (an earlier written "code") were rewritten and recast. While the core or the commonly practised adat were included in the Adat Iban Order, variations among the riverine groups were excluded No similar formal codification exists in Sabah, but there is a list of administrative codes compiled by G. C. Wooley, Esq which include Adat Timogun (1936, reprinted in 1962), Adat Tuaran (1937, reprinted in 1953), Murut Adat (1939 reprinted 1953), Dusun Adat, Putatan and Papar (1953), Dusun Adat, Tambunan and Ranau (1953), Kwijau Adat (1939, reprinted 1953), Dusun Custom in Putatan District (1932, reprinted 1962), which form the basis of customary laws in Sabah. Some native customs have been incorporated into statutes like the Land Code (Cap. 81) Sabah Land Ordinance and are used as a basis of customary land rights. 
Judicial interpretations of those statutory provisions, as well as native laws and customs and traditions, constitute part of the most important sources of customary laws today.

There are a few written records of the customs as applied in the courts. Justice Lee Hun Hoe, a former judge, had compiled the decisions of the Native Court in Sabah and Sarawak in Lee Hun Hoe, Cases on Native Customary Law in Sabah, 1973; Lee Hun Hoe, Cases on Native Customary Law in Sarawak, 1973 and Justice Syed Ahmad Idid bin Syed Abdullah Idid compiled the decisions of the Native Court in Sabah in Native Courts and Customary Law of Sabah (With Cases and Decisions) 1993. The Sabah Law Association have recorded some of the significant decisions in Sabah Native Court of Appeal (1989-2009). Barry Hooker has done an excellent analysis of the different ways in which customary laws have been incorporated into the formal legal system and documented some of the customs in both Sarawak and Sabah (Hooker, 1979). Still, much of native laws remain unrecorded oral traditions, especially where they contain elements of the spiritual and supernatural. Handed down from generation to generation, to the extent that they accommodate the changing realities, they evolve and are flexible.

Customs and oral histories are often peculiar to each locality and might be unknown outside of the immediate sphere of the community, making the establishment of proof uniquely local. Thus in a conflict, it has primarily been the courts which had to determine the customs' existence, either by declaring that a certain practice is indeed an accepted custom or by distinguishing between a certain custom that exists in one locality from customs that exist in another locality.

A number of tests have been relied upon to determine the existence, validity and proof of customs. Sir William Blackstone in his "Commentary on the Laws of England (1765-1769 suggested that the custom must be immemorial, reasonable, continuous, peaceable, certain or clear, compulsory (not optional) and consistent with other recognised customs. These were the guidelines that Rajah Charles Brooke used in Sarawak for his administrators and adjudicators in the performance of their dual duties in the District and Resident's courts. Their Incorporation is evident in the Laws of Sarawak Order L-4 1928 which provided that customs had to be "reasonable and not offend humanity, morality and public policy" (Civil Law Ordinance 1938, s. 3). They should not be "inhumane, unconscionable or repugnant" (Edet v Essien [1932] 11 Nigerian Law Report 47) to good administration (Guidance, 420). These factors have been included in the Native Courts Ordinance 1992 (Sarawak) where s 6 (1) provides that applicable native law and custom be "not repugnant to natural justice or morality or is not ..., in conflict with the provisions of any law in force in the state". In Sabah, Native Courts are empowered to inflict customary modes of punishment so long as it is 
not repugnant to natural justice and humanity (Native Courts Enactment 1992, section 10 (1) (d)). Reasonableness of the practice is an important foundation against which the behaviour and practices of those communities within the particular territory are measured.

The jurisdiction of the Native Courts are limited to cases arising from breaches of native law and customs between natives. These include customs in respect of religious, matrimonial, or sexual offences, and customs relating to betrothal, marriage, divorce, nullity of marriage, judicial separation, adoption, guardianship or custody of infants, maintenance of dependants and legitimacy, gifts of succession, testate and intestate, and any other cases where jurisdiction is conferred on it by Native Courts Enactment (Sabah) or Native Courts Ordinance (Sarawak) or any other written law. The Native Courts have jurisdiction to hear minor criminal offences that do not fall under the Penal Code, with power to impose fines, imprisonment or both (Native Courts Criminal Jurisdiction Act 1991 (Act 471)). In respect of other cases, which are not penal in nature, Native Courts may make orders as may be just and equitable in accordance with native law and customs (Native Courts Enactment 1992, section 10 (2)). Whether in civil or criminal cases, the proceedings in these courts are more inquisitorial rather than adversarial, and two assessors from the relevant community may assist an adjudicator. No lawyers are allowed in the lower courts but they may be permitted in the Court of Appeal where cases involving questions of law are heard before a High Court judge (Native Court Ordinance 1992). In minor criminal matters, where Native Courts have jurisdiction, the emphasis is more restitutionary rather than punitive. (Bulan, $R, 2008$ at $p$ 155). The main objective is a speedy settlement and substantial justice between the parties without undue regard to technicalities, so proceedings shall not be void by reason only of a defect in procedure.

One of the most significant developments and perhaps the most problematic with regards to native laws and customs is proof of native rights to customary lands. As the Native Courts' jurisdiction is limited to disputes on lands without a documentary title between natives, where one party is not a native, especially where provisional leases are involved, the matter is dealt with by federal civil courts. In recent years there has been an increase in litigation involving native claimants and non-native plantation owners, logging concessionaires as well as against the state government. In litigations involving customary land rights, the question of proof and the treatment of native oral histories is endemic. At common law, the existence of customs are a question of fact which must be proved. It falls on the civil courts to determine what and whether certain customary practices applied or existed. This brings into question the proper approach to the treatment of evidence. 


\section{Oral Histories and the Unique Evidentiary Burden Of Proof of Native Laws and Customs: Giving Due Weight to Native Peoples Perspectives}

Recognition of indigenous land rights begin with recognition of indigenous legal traditions and customs on land which may be proved by reference to works of writers, public records, village oral traditions and the opinion of persons likely to know of the existence of such traditions (Sagong Tasi \& Ors $v$ Kerajaan Negeri Johor [2002] 2 Malayan Law Journal 591. As courts may be confronted with conflicting views on the applicable customary laws, an alleged rule of customary law must be "proved in the first instance by calling witnesses acquainted with the native custom until the particular customs have, by frequent proofs in the courts, become so notorious that the courts will take judicial notice of them" (Angu v Attah [1916] Privy Council Gold Coast 1874-1928, 43). This was also expressed by Haidar Bin Mohd J (as he then was) in Hamit bin Mattussin $\mathcal{E}$ Ors $v$ Superintendent of Lands $\mathcal{E}$ Surveys $\mathcal{E}$ Anor ([1991] 2 CLJ 1524). He said, one of the first methods of proof, "consists of the testimony of a witness who deposes, from his own personal knowledge to the actual existence of custom or usage". That evidence "may be based on observation of many instances, and may sometimes be based on reputation or hearsay" (Cross, 1967). Failure to call witnesses to testify to the existence of a customary practice may be fatal to a claim as illustrated in Lah Anyie $\mathcal{E}$ Ors $v$ IOI-Pelita \& State of Sarawak, where the Kenyah custom of 'bulak' or pindah, meaning, to migrate to a new territory was in question. When it was claimed that the Berawan, the original native customary title holders had a similar custom, the failure to call a Berawan to testify to that effect worked against the native claimants (Government of Sarawak v Lah Anyie v IOI- Pelita [2014]).

It is important to prove occupation and customs, which stems from the general common law rule of gaining title to land through occupancy. As Blackstone put it, "occupancy is the thing by which the title was in fact originally gained, every man seizing such spot of the ground as he gained most agreeable to his convenience, provided he found them unoccupied by someone else (Mabo [No.2] v Queensland [1992] 175 Commonwealth Law Reports 1. For native peoples, this evidence is contained in oral history and narratives. Two of the earliest Malaysian cases on common law recognition of customary rights to land, namely Sagong bin Tasi and Ors v Kerajaan Negeri Selangor and Ors ('Sagong I') and Nor anak Nyawai \& Ors $v$ Superintendent of Lands \& Surveys [2001] 6 Malayan Law Journal 241), took oral histories as evidence. In Nor Nyawai, oral narratives and histories of the Iban and expert evidence were adduced and admitted to prove customary practices of the Iban community. The customs that were admitted as proof of title and evidence have specific contents and implications for native customary rights 
and interests in customary lands. These precedents have been followed in subsequent cases including Sagong bin Tasi v Kerajaan Negeri Selangor ([2002] 2 Malayan Law Journal 591).

In Sagong Tasi's case, Mohd Noor Ahmad J ruled that oral histories of the Orang Asli relating to their practices, customs, traditions and their relationship with the land be admitted as evidence subject to the terms of the Evidence Act 1950, s 32(d) and (e). Oral history was challenged as offending the hearsay rule, to which he said:

The first principle relates to the difficulties inherent in demonstrating continuity between current aboriginal activities and the pre-contact practices, customs and traditions of aboriginal societies. Since many aboriginal societies did not keep written records at the time of the contact or sovereignty, it would be exceedingly difficult for him to produce conclusive evidence from pre-contact times about practices, customs and traditions and their community. The second principle is to adapt the laws of evidence so that the aboriginal perspective on their practices, customs and traditions and on their relationship on the land, are given due weight by the courts. In practical terms, this requires the courts to come to terms with oral histories of aboriginal societies which, for many aboriginal nations, are the only record of the past (Sagong bin Tasi $v$ Kerajaan Negeri Selangor [2002] at 2 Malayan Law Journal 591, 622).

Mohd Nor J also ruled that the statements on oral histories must be of public and general interest; made by a competent person who "would have been likely to be aware" of the existence of the right or the correct customs; and must be made before the controversy as to the right or the customs (Sagong bin Tasi v Kerajaan Negeri Selangor [2002] 2 Malayan Law Journal 591, 623). Sections 48 and 49 of the Evidence Act 1950 allow for the opinions of a living person as to general rights or customs, tenets or usages.

A contention raised against the enforcement of customary land rights is the view that custom or adat covers only social etiquette or norms of correct social behaviour. Customs, it is argued, become customary laws only when they are codified (Fong, 2007). Central to this argument is the meaning given to the phrase "custom and usage having the force of law", where "law" is taken to be only written law. It is also contended that these customs were "not part of the Rajah's legislation or codified" and "although practised, are not part of native customary law (Ibid, 36). He argued that [written] laws and codified customs "provided a degree of certainty and stability in the implementation of the state's development 
goals (Myth, Facts and Reality, 2009, p. 34). While that may be so, however, expediency should not be the primary determinant.

Ian Chin J's decision in Nor anak Nyawai v Borneo Pulp Plantations, [2001] 6 MLJ 241, 268, is significant as he recognised and referred to adat as a "practice by the habit of a people and not by the dictates of the written law". Furthermore, he held that "customs are not dependent for their existence on any legislation, executive or judicial declaration. They exist long before any legislation" (Nor Nyawai I [2001] 6 MLJ 241, 268, 287,). The Federal Court affirmed this in Madeli bin Salleh $v$ Superintendent of Lands and Surveys, Miri Division \& Anor ([2005] 5 Malayan Law Journal 305). Although many of the customs have been codified, the codification is not exhaustive. Customary codes are reproductions in written form, of customs that have evolved up to a certain point in time. Indeed, some of the most important customs that have not been codified are ancient customs relating to land tenure, which continue to be practised by various native groups.

In Chin J described native customary rights (NCR) in the words of Brennan $\mathrm{J}$ in Mabo No 2, saying that "it has its origins and is given its content by the traditional laws acknowledged by and the traditional customs observed by the indigenous inhabitants of the territory". This significant statement recognises how the native psyche is intertwined with land. Their customs lie at the core of the economic, spiritual and cultural longevity of native communities and touch on the fundamental aspects of their values as communities. This is clearly borne out in Nor anak Nyawai where the Iban customary practice of pemakai menoa, or customary territorial domain, is declared as a valid existing custom of the Ibans.

At this juncture, it is instructive to say something about NCR to land and the statutory provisions through which they are acquired in Sarawak. The relevant law is embodied in section 5 sub s (1) of the Land Code 1957 Cap.81. which provides that, as from January 1st 1958, "native customary rights may be created" in accordance with native customary law of the community or communities concerned, by the methods specified in section 5(2) which are: the felling of virgin jungle and the occupation of the land thereby cleared, planting of land with fruits, occupation of cultivated land, use of land for a burial ground or shrine, use of land for rights of way, and by any lawful method. Although the last limb "any lawful means" was deleted in 2000, it had not been enforced. An amendment of the Land Code (Cap.81) in 2018 had, perhaps for the need for clarity, reinstated the latter.

NCR to land should also be understood in the context of classification of land under the code, namely: Mixed Zone (lands that may be held by any citizen without restriction), Native Area Land (land with a registered document of title, to be held by natives only) (Land Code Cap. 81, under (4(2) or (3) or (4)(b) or s 38(5)) Native Communal Reserve (declared by Order of the Governor in Council 
for use by any native community and regulated by the customary law of the community (s 6(1) ), Reserved Land (lands reserved for public purposes (s 7 (1) ), Interior Area Lands (land that does not fall under Mixed Zone or Native Area Land or Reserved Land and for which title cannot be registered) and Native Customary Land (land in which customary rights whether communal or otherwise, have been created). By virtue of this classification, native customary lands can only be created in Interior Area Land ( $s$ 4(2). This is the area that is inhabited by most native communities. (Bulan R \& Amy Locklear, 2008)

No native customary land may be created after January 1958 except with a permit obtained from the Minister under section 10 of the Land Code. In 1996, s 5(3) of the Land Code was amended to include a provision that any occupation of land apart from the provisions of the Land Code is unlawful "despite any customs to the contrary". This begs the question whether such a statutory provision by one single draconian stroke should rightly terminate the application of customs and ancient traditions that have governed the lives of indigenous communities? Should the constitutionality of that provision be called to question, would it stand in the face of the broad definition of law and the safeguards given to native customs? This calls to mind Lord Haldane's admonition in Amodu Tijani v Secretary, Southern Nigeria [1921] 2 Appeal Cases 399,) that the nature and content of such rights require an examination of the customs and practices of each individual community. This involves a factual inquiry and not whether the customs appear in the statute book (Agi ak Bungkong \& Ors v Ladang Sawit Bintulu Sdn Bhd [2010] 4 Malayan Law Journal 204,). An illustration of this is provided in Nor Nyawai \& Ors $v$ Borneo Pulp Plantations Sdn Bhd E Ors (Nor Nyawai) [2001] 2 CLJ 769

\section{Factual Inquiry and Examination of Customs and Practices of an Individual Community: The Pemakai Menua Deliberation}

In Nor Nyawai \& Ors v Borneo Pulp Plantations Sdn Bhd \& Ors [2001] 2 CLJ 769, the Iban plaintiffs based their claim on their exclusive use and occupation of the land under a system of customary territorial control of the land. Under Iban customs, they had acquired native customary rights to lands which they regarded as pemakai menoa (literally, "land to eat from"), part of which had been encroached upon. The question at the High Court as well as the Court of Appeal was whether the Iban customs of creating pemakai menoa, the temuda (formerly cultivated lands at various stages of young wild growth) and pulau galau (customary communal forest reserve) were the same customs practised by their ancestors and whether recognised by law, and if so, whether they conferred rights over land. Have those 
customs been abolished through "clear and plain" intention by order of the Brooke Rajahs or by subsequent legislation?

The claimants' Iban identity was easily established through the Iban language that they as they all spoke. Upon admission of expert oral evidence, the High Court recognised their pre-existing rights to lands, as evidenced by their existence as a community surviving and in control of the land. Under Iban custom, each longhouse community has a distinct territory and area of land over which they have control. This is exercised within a garis menoa - territorial boundaries between villages marked by rivers, hills, clumps of trees or other natural features. Evidences of expert witnesses of Nicholas Bawin and Empeni Lang in Agi Bungkong, p 213 explain that the territorial domain is the pemakai menoa which encompasses the tana umai (cultivated lands- farms and gardens), temuda, (formerly cultivated land which has been left to regrow into a secondary forest), tembawai (old longhouse sites) and pulau galau, a forest reserve or land that is left uncultivated, for communal use. Such communally used areas provide the supply of natural resources such as rattan, ferns, bamboo shoots and other jungle produce, and include areas for water catchment, hunting and fishing areas, and land reserved to honour a distinguished (deceased) person called pulau. The pulau may be owned by a single village or shared between two or more village communities (Dimbab Ngidang, 2003) and (Ngidang, 2005).

The recognition of the Iban customary practice of pemakai menoa was significant because it epitomised the existence of traditional forms of occupation, albeit not specified under the five limbs of s 5 of the Land Code. Despite increasing comprehensive regulatory legislation, Ian Chin J found that customary rights associated with the terms temuda, pulau and pemakai menoa had not been abolished by any of the Brooke Orders, Ordinances or the code or any other statute. The Ibans were acknowledged to be rightfully in possession of their customary lands.

On appeal, in Superintendent of Lands \& Surveys \& Ors $v$ Nor Nyawai, the respondents (including the state) argued that recognition of NCR under the Land Code 1958 could only be through the creation of temuda and not simply by roaming or foraging. It was also argued that the terms pulau and pemakai menoa did not appear in any of the statutes, nor in the codified Iban Adat. On 9 July 2005, the Court of Appeal granted the appellants' appeal against the grant of compensation to the plaintiffs (Superintendent of Lands \& Surveys Bintulu $v$ Nor Anak Nyawai and Ors) [2005). While the Iban had satisfied the test for native customary rights in the adjacent area, there was insufficient proof of occupation in the disputed area. The Court of Appeal required proof of actual cultivated areas or temuda, and declared that the claim for native customary rights should not be extended to areas where "they used to roam to forage for their livelihood in accordance with their 
tradition". The Appeal Court followed their own conclusion in Kerajaan Negeri Selangor $v$ Sagong Tasi which was decided a few months prior to the instant appeal decision. With respect, it must be submitted that declaration was wrong in principle. The comment of the court in Sagong Tasi was merely obiter dictum, as the claim in Sagong Tasi was for compensation for their settlement and not for foraging areas. Any comment on the latter was a statement by the way and cannot be taken as binding. Be that as it may, notably, the Court of Appeal ([2006] 1 Malayan Law Journal 256) did not overturn the High Court's statement of the law that preexisting rights had not been abrogated by statutes and that customary laws exist independent of written law, or executive directives. This is significant.

This illustrates how indigenous traditional knowledge that underpins the social and physical aspects, as well as the ceremonial practices governing indigenous peoples' peculiar cultural relationship with their land may not be captured fully in written codes. Evidence of occupation and connection with the land is often in their narratives, the taxonomy of rivers and sites on the land, stories, songs and ballads. These narratives speak of peoples' proprietary rights, responsibilities on the land and tell of regimes that govern relationships to the land. They provide the factual, social, and psychological contexts that must be given weight, in litigation involving those lands (Borrows, 2001). The evidentiary standards required to prove native customs on which rights are anchored, clearly, indicate that stories matter. To quote Chief Justice Lamer, "a court should approach the rules of evidence, and interpret the evidence that exists, with a consciousness of the special nature of aboriginal claims" (Delgamuukw v British Columbia (1997) 3 Supreme Court Report 1010, To borrow the words of Lamer CJ, Ian Chin's decision was a "profound effort to reconcile how different peoples with different cultural traditions see the world (Lamer CJ in Delgamuukw (1997) \# SCR 1010, at 1069 In his groundbreaking decision, the learned judge considered the evidence before him and gave due weight to the native law perspectives.

Almost a decade later, David Wong Dak Wah J (as he then was) had a fresh look at native customary practices relating to land in Agi Bungkong \& Ors $v$ Ladang Sawit Bintulu Sdn Bhd ([2010] 4 Malayan Law Journal 204) In that case two provisional leases were granted to the defendants. The plaintiffs claimed that their customary land was within the defendants' parcel. They claimed NCR on the lands based on the Iban custom of pemakai menoa. The defendants objected on the grounds that the custom was not recognised in law. Two experts were called to explain the nature of the pemakai menoa and the rituals involved in the creation of it. According to the expert evidence of Nicholas Bawin, the establishment of a new pemakai menoa involved rituals called the panggul menoa. Empeni Lang, a former Registrar of the Native Court explained that "the pemakai menoa defines the 
territorial jurisdiction of each Tuai Rumah [headman] and it is this jurisdiction of Tuai Rumah that is defined or implied in s 7 of the Native Court Ordinance 1992. Without the concept of pemakai menoa, there would be no clear definition and extent of the local jurisdiction of the Tuai Rumah as the presiding officer of the headman in the Native Court system. Empeni Lang also explained how temuda, may be transferred to subsequent generations and how lands within the pemakai menoa may be left under a fallow system to maximise land fertility and to enhance use. Following the Court of Appeal decision in Nor Nyawai, Wong J did not hesitate in holding that the pemakai menoa is an Iban custom and practice. Furthermore, the learned judge held that the view was "consistent with the intention of the Federal Constitution which defines law to include "custom and usage having the force of law in the Federation or any part thereof." The court referred to earlier authorities and held that "native title requires an examination of the customs and practices of each individual community and this involves a factual inquiry and not whether the customs appear in the statute book" (Agi Bungkong $v$ Superintedent of Land $\mathcal{E}$ Surveys, Kuching [2010] 4 Malayan Law Journal 204, 215,).

One of the arguments against recognition of pemakai menoa as expressed in Bisi Jinggut $v$ Superintendent of Lands, Kuching (2014) is that "it may mean that vast area of land would be under native customary rights simply through assertions by some natives that they and their ancestors had roamed or foraged the areas in search for food and for sustenance This was rejected by Rodziah Bujang JC (as she then was) in a later case involving the Bidayuh. Referring to Ian Chin's decision in Nor Nyawai's case, she opined that the equivalent Bidayuh concept of tonyoh or kompokng must be similar, and rejected the concept would produce an alarming result. She referred to adduced evidence that the right to forage is limited by custom to just a half day's walk. And opined that "without any clear pronouncement to the contrary, I am not persuaded that the concept of using land to forage for livelihood and sustenance is not part of native customary rights before the cut-off date specified in section 5(1) of the Land Code."

Pemakai menoa was again the subject of an appeal by the state government in Director of Forest, Sarawak \& Anor v Tuai Rumah Sandah ak Tabau \& Ors ([2014] 1 Malayan Law Journal 161). The respondents in the appeal were Iban who had obtained from the High Court a declaration, inter alia, that they had acquired from their ancestors native customary rights ('NCR') and/or usufructuary rights over 2,712 hectares of primary forest ('the primary forest') in the Kanowit-Ngemah state forest area in Sarawak. The Director of Forests did not dispute the existence of such Iban customs of pemakai menoa and pulau but he appealed on the grounds that there is no statutory recognition that appellants could acquire NCR to the primary forest, and that Sarawak only recognised the temuda as capable of giving rise to 
NCR. The Court of Appeal sought to deal with the same questions that were raised in earlier cases thus:

(a) Whether the custom of 'pemakai menoa' and 'pulau' falls within (i) the definition of 'law' under art 160(2) of the Federal Constitution; or

(b) Whether the term 'native customary law' as defined in the Land Code of Sarawak and the Native Courts Ordinance (Cap. 431958 Edition of Laws Sarawak) which came into force on 1 September 1955 recognises the said customs of 'pemakai menoa' and 'pulau' in relation to the creation or acquisition of 'rights over land' in Sarawak; alternatively or precisely;

(c) Is native customary rights over land confined to 'temuda' land? or, in the further alternative;

(d) Has the custom of pemakai menoa been given the effect to by the law of Sarawak?

The appeal by the Director of Forests at the Court of Appeal was dismissed on the grounds that the claim to the pulau was a bona fide claim. In the absence of a clear an unambiguous word in legislation to repeal or reject pre-existing customary rights established under pre-existing native customs, the common law applicable in Sarawak recognised the NCR inherited by the respondents from their ancestors. Their rights were established in the early 1800s over the 2721 hectares claimed as land set aside as pemakai menoa under the native customs of pulau and that right cannot be taken away without compensation. The Court went further to state that the pemakai menoa was an inherent right. The sovereign right to title within the state was not absolute but subject to unextinguished pre-existing rights. As to the legal effect at law, it did not matter that the concept was not included in the codified Adat Iban. Once again the Appeal Court pointed to the definition of law in the Federal Constitution.

Reference was made to Superintendent of Lands $\mathcal{E}$ Surveys Miri $v$ Madeli bin Salleh [2007] MLJU 805, [2007] 6 CLJ 509 where the Federal Court categorically stated that common law which is part of Malaysian law has the same effect as written law. By implication, as common law recognised native law and customs, it is recognised by law. The Federal Court affirmed that such rights do not owe their existence to statutes. They are inherent rights that can only be extinguished through clear and unambiguous words of the legislation. The court also noted that the customs and practices evolve from and in response to changing circumstances and have gained general acceptance. Traversing a broad range of communal interest, it is suggested that this in a sense is a direct democracy. 
In a further explication of its own decision, the Court of Appeal reaffirmed its recognition of pulau galau in Superintendent of Lands and Surveys Department Sibu Division \& Anor v Usang ak Labit \& Ors and another appeal (Usang Labit). The decision of Wahab Patail JCA bears reproducing where he said

It is true that not all produce or products in a pulau galau are derived directly from the land. But it stands to reason that produce and products derived directly from the land, be it its mineral or formation such as caves or cliffs for birds' nests, necessarily means it is a right related to land for without the land the right to the produce and products could not be enjoyed, benefited from or accessed. Equally true and for the same reason, for produce or products derived indirectly, ... from the forest in the pulau galau. Without the land, the native customary right of the use of pulau galau can no longer be exercised. The custom of pulau galau is therefore a native custom so inextricably wrapped and tied up with the land it is upon that it is as much a native custom to land as the tanah umai and the fallow lands in the temuda. Hence, it has always been part of the native custom that the 'pulau galau' is part of the menoa or pemakai menoa [2014] 3 Malayan Law Journal 519 at 530.

On appeal by the Director of Forest to the Federal Court, those same questions were brought up to be decided. While the majority agreed with the fact of the existence of the custom of pemakai menoa, it was held that the customs did not have the force of law under Art 160 of the Constitution. Raus PCA (as he then was) opined that "as a matter of fact common law as developed in Malaysia further requires occupation and or maintenance of the land in question". Thus he felt that the custom did not satisfy common law requirements. What his Lordship failed to appreciate was that a right under customs does not require the same occupational content as common law.

He also said that the custom did not have force of law because it was not included in written records including the Iban Tusun Tunggu and the Iban Adat Order. With respect, this writer argues that such a decision lacks a full understanding of the place of adat as a source of law under the constitutional definition of law. It falls short of the "on the ground "context and realities governing the life of the relevant community and others similar to it. The decision of the dissenting judge showed a better understanding of the jurisprudential basis of the customs and the proprietary rights that arose under it. In her dissenting judgement Zainun Ali FCJ said: 
Contextually, temuda exists BECAUSE it is part of pemakai menoa. To disembody pemakai menoa and pulau from temuda makes little sense, because if the concept of Iban territorial domain is properly understood, one would at once acknowledge the relationship of various land rights in its context. Therefore in the absence of a clear provision in statute which rejects the custom of pulau, the existence of pulau is recognised by common law. Director of Forests $v$ TR Sandah \& ors [2017] 2 MLJ 281, p341 at para 210.

With respect, the dissenting view ought to be an acceptable position. A review of the decision by the Federal Court handed down on 14 September 2019 in Putrajaya did not disturb the earlier decision of the Federal Court. Only one judge dissented bringing into sharp relief the importance of judicial contextualisation of native laws and customs at the time of writing, the written decision of the court was not yet available

\section{The need for judicial contextualisation of native laws and customs}

The decision of the Federal Court in Tuai Rumah Sandah shows again that the application of customary laws in context requires an understanding of the community's legal traditions. Like all legal traditions, they are permeable and subject to cross-cutting influences and must continually be reinterpreted to and reapplied in order to be relevant amidst changing conditions. A noteworthy case in point is Mohd Rambli bin Kawi v Superintendent of Lands, Kuching [2010] 8 MLJ 441. There, David Wong J (as he then was) considered whether Malay, customary land rights included the swampland around their kampung on which they foraged and depended for their livelihood and whether by Malay customs, a Malay can transfer NCR lands to members of the same or other native communities.

Through oral evidence and narratives of respected members of the Malay community, it was evident that according to Malay customs, a pioneer who occupies an area for farming, for the planting of crops or fruit trees, or generally for 'cari makan' (foraging for food or general use of the land for livelihood purposes), could claim rights over the said land. The plaintiff and others claimed that it was fundamental to the social, cultural and spiritual aspects of Malay life. It was "not just for their livelihood, it was life itself". This appeared to be similar to the concept of pemakai menoa. The said land could be inherited by their descendants and may be transferred by custom called 'serah', or surrendered to another person or another native who may not necessarily be of Malay race but is a native of Sarawak. Wong J held that there was nothing in the Malay customs that prohibited the transfer. The concept of 'serah' had evolved to the point that the 
"serah" involved a Surat Perjanjian Menyerah Tanah Temuda (a document of transfer) which was recognised by the Lands and Surveys Department. Recognition of that custom was not dependent on the statute.

It bears restating that common law, recognises but does not create native customary rights to land (Superintendent of Lands $\mathcal{E}$ Surveys $\mathcal{E}$ Government of Malaysia v Madeli bin Salleh [2008] 2 Malayan Law Journal 212, Case 14). They are unique, sui generis rights sourced in native laws and customs but recognised by other sources of law. The Federal Court and the courts below appear to conflate common law and customary laws and has yet to fully elucidate on the connection between the occupation on the land and the customs that underpin that right. There is a danger of misinterpretation of the substance if the courts merely interpret the customary rights through the lenses of common law concepts. It is this mischief of (mis)interpretation that Lord Haldane warned against in the Privy Council case of Amodu Tijani v Secretary, Southern Nigeria where His Lordship pointed to "a tendency, operating at times unconsciously, to render [native] title conceptually in terms which are appropriate only to systems which have grown up under English law." His Lordship said that "this tendency has to be held in check closely". The dangers of looking at indigenous law purely through common law lenses are obvious. The two systems of law developed in different situations, cultural contexts and in response to different conditions. As Lord Haldane further observed, in Amodu Tijani v The Secretary, Southern Nigeria [1921] 2 AC 399 at 403),

The title, such as it is, may not be that of the individual, as in this country it nearly always is in some form, but maybe that of a community...To ascertain how far this latter development of right has progressed involves the study of the history of the particular community and its usages in each case. Abstract principles fashioned a priori are of but little assistance, and are as often as not misleading.

To avoid a miscarriage of justice, courts should examine such customs free from the limited notions of English common law property rights. Ian Chin J's decision in Nor Nyawai that the licence was "not terminable at will" was meant to avoid that mistake. The determination of the real character of indigenous title to land, therefore, involves the study of the history of a particular community and its usages to determine the true nature of the customary right in question. Each community's customs must be treated on their own terms. In a similar vein, in Oyekan and Others $v$ Adele Oyekan' [1957] 2 All ER 785, the Privy Council ruled that customs, and not English common law concepts of property, must control the determination of the rights held under native title so that disputes between 
inhabitants regarding property rights were determined under native law and custom without importing English conceptions of property. Seeking to interpret those rights purely through English law concepts was unwise and unproductive, and ultimately undermined the object of recognition. For this reason, the caution administered by the Privy Council was referred to at length by the Court of Appeal in Sagong Tasi v Kerajaan of Selangor [2001] 2 Malayan Law Journal 591. Those rights cannot be deprived without adequate compensation under the Constitution.

\section{Conclusion}

The preceding cases illustrate the determination of indigenous conceptions of property ownership by the courts. Each case brings incremental knowledge and understanding of the issues. To various degrees, the judges attempted to clarify the nature and extent of the rights under native laws and customs, Despite some recognition in a number of judicial decisions, the cases also show the tendency of the state to lean towards legislation as the only determinant for legality and validity founded on the view that societies only possess enforceable laws if they are declared by some recognised power that is capable of enforcing those laws. Indigenous legal traditions are seen as holding only moral force and therefore not clothed with legality. Philosopher John Austin expressed the idea that "before it (custom) is adopted by the courts and clothed with legal sanction, it is merely a rule of positive morality". Those who argue with Austin's view say that his view rests on inaccurate assumptions about the law (Finnis, 2000) because not all laws flow from sovereign authority or explicit command (Fuller, 1958). Sometimes customs are belittled by scholars like Austin because they are considered inferior, and "primitive" law of "savages" ( Austin, 1995, p. 176) who are at the lowest hierarchy of civilisation. Even if native communities practised customary laws exclusively, to say that they only have moral force is misleading. This kind of approach that discounts indigenous customs was condemned in the case of Calder v AG of British Columbia (1973) SCR 313 at 346-where the Supreme Court of Canada saying that such interpretations were formulated" when understanding of customs and culture of our original people was rudimentary and incomplete and when they were thought to be wholly without cohesion, laws or culture, in effect subhuman species

There should not be any such complaint in Sabah and Sarawak since native law and customs have always been recognised. 'Custom and usages' is entrenched in Malaysian law where the basic principle underpinning that recognition points to equality for all persons before the law as guaranteed under Article 8(1) of the Federal Constitution. Art 8(2) prohibits discrimination against citizens based on 
their race or descent in regard to any law relating to the holding or disposition of property. With respect to property rights, the principle of equality requires that native communities be provided with the same protections accorded to non-native communities. This means giving due weight to indigenous peoples perspectives and recognising their property rights under customary laws on their own terms. This includes a unique approach to the treatment of evidence under native laws and customs, and oral histories and traditions.

Indigenous traditions are not static. As John Borrows says, "their strength lies in their ability to survive through the power of tribal memory and to renew themselves by incorporating new elements as they remain relevant under changing circumstances" (Borrows, 2011, p.60). The form be may adapted to new conditions while the traditional normative rules remain. As a renowned researcher and officer in Sarawak's colonial service rightly pointed out, "anyone with experience must know, despite its theory of rigid conservatism, "applied adat" is a flexible and changing thing" which is modified to suit changing conditions in order to be relevant to the community concerned (Leach, 1947).

In practical terms, judges must inquire into "the factual, social and psychological context within which the litigation arises" (Borrows, 2001, p.1). That conscious, contextual inquiry would be a step towards judicial impartiality, creativity, non-discrimination and recognition of customary laws as living and an equally important body of laws. The rights imbedded in customary laws are unique, sui generis rights which must and must be construed within the spirit and intendment of the supreme law, the Federal Constitution.

\section{Acknowledgements}

The author would like to thank and acknowledge the financial support provided by the University of Malaya for the research grant RP2005A/HNE13. The author also acknowledges the contributions made by the research participants who patiently took part in this study. This study would not be possible without their assistance.

\section{References}

Austin, J. (1995). The Province of Jurisprudence Determined, Vol. 1. Cambridge: Cambridge University Press.

Bulan, R, Resolution of Conflict and Disputes under Kelabit Customary Laws in Sarawak, in Zawawi Ibrahim (ed). Representation, Identity and 
Multiculturalism in Sarawak, Dayak Cultural Foundation and Persatuan Sains Sosial Malaysia, 2008, 155-174.

Bulan R, and Amy Locklear, Legal Perspectives on Native Customary Land Rights in Sarawak, Suhakam 2008.

Borrows, J. (2011). Canada's Indigenous Constitution. Toronto: University of Toronto Press. Borrows, J. (2001). Listening for a Change: The Courts and Oral Tradition. Osgoode Hall Law Journal, 39(1), 1-38.

Burns, P. (2004). The Leiden legacy: Concepts of law in Indonesia (p. 1). Leiden: KITLV Press.

Civil Law Ordinance 1938.

Cross, R. (1967). Cross on Evidence. London: Butterworth \& Co.

Finnis, J. (2000). On the Incoherence of Legal Positivism. Notre Dame Law, 75(5), 1597-1612.

Fong, J. C. (2007). Native Customary Laws and Native Rights Over Land in Sarawak. In SUHAKAM (Ed.), Penan in Ulu Belaga: Right to Land and Socio-Economic Development (p. 175). Kuala Lumpur: Human Rights Commission of Malaysia.

Fuller, L. (1958). Positivism and Fidelity to Law: A Reply to Professor Hart. Harvard Law Review, 71(4), 630-672.

Hooker, M. B. (1972). Adat Laws in Modern Malaya, Land Tenure, Traditional Government and Religion. Kuala Lumpur: Oxford Univeristy Press.

Hooker, M. B. (1978). Adat Law in Modern Indonesia. Oxford: Oxford University Press.

Langub, J. (1998). The Ritual Aspects of Customary Law in Sarawak with Particular Reference to the Iban. Journal of Malaysian and Comparative Law, 25, 45-60.

Leach, D. J. (1947). Law and Custom. Sarawak Gazette, 151.

Myth, Facts and Reality of EU FLEGT- VPA: Sarawak's Perspective. (2009). Kuching: Sarawak Timber Association.

Ngidang, D. (2003). Transformation of the Iban land use system in post independence Sarawak. Borneo Research Bulletin, 34, 62-79.

Ngidang, D. (2005). Deconstruction and reconstruction of native customary land tenure in Sarawak. Japanese Journal of Southeast Asian Studies, 43(1), 4775 .

Idid S.A. (Ed.). (1993). Native Court and Customary Law of Sabah (With Cases and Decisions). Kota Kinabalu: Sabah Government Printer.

Ter Haar, B. (1948). Adat law in Indonesia. International Secretariat, Institute of Pacific Relations.

Vollenhoven, C. (1933). Het adatrecht van Nederlandsch-Indië. Brill. 
Walters, M. D. (1999). The "Golden Thread" of Continuity: Aboriginal Customs at Common Law and Under the Constitution Act, 1982. McGill Law Journal, $44,711-752$.

Hamzah, A., \& Bulan, R. (2003). An introduction to the Malaysian legal system. Oxford Fajar Sdn. Bhd..

\section{Cases}

Adong bin Kuwau v Kerajaan Negeri Johor [1997] 1 Malayan Law Journal 4.

Agi ak Bungkong \& Ors v Ladang Sawit Bintulu Sdn Bhd [2010] 4 Malayan Law Journal 204.

Angu v Attah (1916) Privy Council Gold Coast 1874-1928, 43.

Amodu Tijani v Secretary, Southern Nigeria [1921] 2 Appeal Cases 399.

Borneo Pulp Wins Appeal Case on NCR Land. (2005, 9 July). The Sarawak Tribune, p. 3.

Calder et al. v. Attorney-General of British Columbia [1973] S.C.R. 313, 34 Dominion Law Report (3d) 145 In the Goods of Abdullah [1869] 1 Kyshe, 216.

Campbell v Hall (1771) Lofft 6555, 1 Cowp. 204, 98 ER 848 (K.B)

Choa Choon Neo v Spottiswoode [1835] 2 Kyshe. Ecc 8, 11.

Choo Ang Choo v Neo Chan Neo (Six Widows Case) [1911] 12 Straits Settlement Law Reports 120.

Civil Appeal No. 01-1-2006(Q) 24.

Delgamuukw v British Columbia (1997) 3 Supreme Court Report 1010.

Director of Forests \& Or v TR Sandah \& Ors, [2017] 2 Malayan Law Journal 281, Zainun Ali at p 341 para. 210

Edet v Essien (1932) 11 Nigerian Law Report 47.

Jalang anak Paran v Superintendent of Lands [2007] 1 Malayan Law Journal 412.

Keteng bin Haji Li v Tua Kampong Suhaili [1951] Supreme Court Report 9.

Mabo (No. 2) v Queensland (1992) 175 Commonwealth Law Reports 1.

Madeli bin Salleh v Superintendent of Lands and Surveys, Miri \& Anor [2005] 5

Malayan Law Journal 305.

Mason v Triton (1994) 34 New South Wales Law Report 572.

Mohamed Rambli Kawi v Superintendent of Lands, Kuching [2010] 8 Malayan Law Journal 441.

Motor Emporuim v Arumugam (1933) 2 Malayan Law Journal 276.

Nor anak Nyawai \& Ors v Superintendent of Lands \& Surveys [2001] 6 Malayan Law Journal 241. 
Oyekan and others v Adele Oyekan [1957] 2 All England Report 78R v Simon [1985] 2 SCR 387.

R v S (R.D.) [1997] 3 Supreme Court Report 484.

Ramah v Laton [1927] 6 Federated Malay States Law Report 128.

Richtersveld Community (2003) 12 BCLR 1301 (CC), 2003 South African Consitutional Law Report LEXIS 79, *11.

Sagong bin Tasi v Kerajaan Negeri Selangor [2002] 2 Malayan Law Journal 591.

Sahrip v Mitchell \& Anor (1877) Leic. Reports 466.

Superintendent of Lands \& Surveys, Miri v Madeli bi Salleh Kilong [2008] 2 Malayan Law Journal 212.

Superintendent of Lands \& Surveys v Nor anak Nyawai [2006] 1 Malayan Law Journal 256.

Date Received: 16 September 2019 Date of accepted: 1 December 2019 